\title{
Microcrystalline silicon absorber layers prepared at high deposition rates for thin-film tandem solar cells
}

\author{
S. Michard, V. Balmes, M. Meier ${ }^{\mathrm{a}}$, A. Lambertz, T. Merdzhanova, and F. Finger \\ Institute of Energy and Climate Research 5 - Photovoltaik, Forschungszentrum Jülich, 52425 Jülich, Germany
}

Received: 24 July 2013 / Received in final form: 2 October 2013 / Accepted: 8 October 2013

Published online: 6 December 2013

(C) Michard et al., published by EDP Sciences, 2013

\begin{abstract}
We have investigated high deposition rate processes for the fabrication of thin-film silicon tandem solar cells. Microcrystalline silicon absorber layers were prepared under high pressure depletion conditions at an excitation frequency of $81.36 \mathrm{MHz}$. The deposition rate was varied in the range of $0.2 \mathrm{~nm} / \mathrm{s}$ to $3.2 \mathrm{~nm} / \mathrm{s}$ by varying the deposition pressure and deposition power for given electrode spacings. The silane-to-hydrogen process gas mixture was adjusted in each case to prepare optimum phase mixture material. The performance of these tandem solar cells was investigated by external quantum efficiency and current-voltage measurements under AM1.5 illumination before and after $1000 \mathrm{~h}$ of light degradation. Up to deposition rates of $0.8 \mathrm{~nm} / \mathrm{s}$ for the microcrystalline silicon absorber layer high quality tandem solar cells with an initial efficiency of $10.9 \%$ were obtained $(9.9 \%$ stabilized efficiency after $1000 \mathrm{~h}$ of light degradation).
\end{abstract}

\section{Introduction}

Microcrystalline silicon is widely used as absorber layer of the bottom solar cell in the amorphous/microcrystalline thin-film solar cell concept. This solar cell concept was pioneered by research groups in Neuchâtel, Jülich and at Kaneka Corporation [1-3]. The use of stacked solar cells with different optical bandgaps facilitates the efficient utilization of the solar spectrum $[4,5]$. Due to the indirect semiconductor bandgap of microcrystalline silicon a thickness of more than $1 \mu \mathrm{m}$ is favorable to have enough light absorption, particularly in the long wavelength region. Increasing the thickness of the bottom solar cell absorber layer is also one approach to achieve current matching between top and bottom solar cell.

Increasing the efficiency or reducing the manufacturing cost of thin-film solar cells are two approaches to increase the cost competitiveness of the thin-film silicon technology. We investigate processes which target high material growth rates to reduce the fabrication costs per unit and to increase the throughput of the deposition system. Studies on how to reach world record solar cell efficiencies were given by Hänni et al. [6] for $\mu \mathrm{c}-\mathrm{Si}: \mathrm{H}$ single junction solar cells and by Kim et al. [7] and Guha et al. [8] for multijunction solar cells. Further details about the recent developments in the field of thin-film solar cells from research

\footnotetext{
a e-mail: ma.meier@fz-juelich.de
}

scale to industrial scale can be found in a comprehensive overview published by Shah et al. [9].

In this study we investigated based on the results of our earlier studies [10-12] the effect of an increased deposition rate for the $\mu \mathrm{c}-\mathrm{Si}: \mathrm{H}$ absorber layer on the quality of state of the art thin-film tandem solar cells. Here, we also investigate the effect of high deposition rate used for fabrication of $\mu \mathrm{c}-\mathrm{Si}: \mathrm{H}$ bottom cell on the stability of the tandem solar cells under light induced degradation. To achieve high deposition rates while maintaining the material quality two approaches were combined. These were: deposition processes in the high pressure depletion (HPD) regime $[13,14]$, and the use of high excitation frequencies in the VHF band $\left(\nu_{\mathrm{ex}}>30 \mathrm{MHz}\right)[15-17]$.

\section{Experimental details}

For the device fabrication commercially available glass covered with $\mathrm{SnO} 2 \mathrm{~F}$ (Asahi type VU) served as substrate. Silicon layers were deposited by plasma enhanced chemical vapor deposition (PECVD) on $10 \mathrm{~cm} \times 10 \mathrm{~cm}$ large substrates using a clustertool deposition system which is described in detail in reference [12]. For the a-Si:H top solar cell and the $\mu \mathrm{c}-\mathrm{Si}: \mathrm{H}$ bottom solar cell the p-i-n deposition sequence was used in the superstrate configuration. The top solar cell is formed by a layer stack consisting of p-type a-SiC:H, intrinsic a-Si:H, and n-type $\mu \mathrm{c}-\mathrm{Si}: \mathrm{H}$ layers. The bottom solar cell is formed by a layer stack 


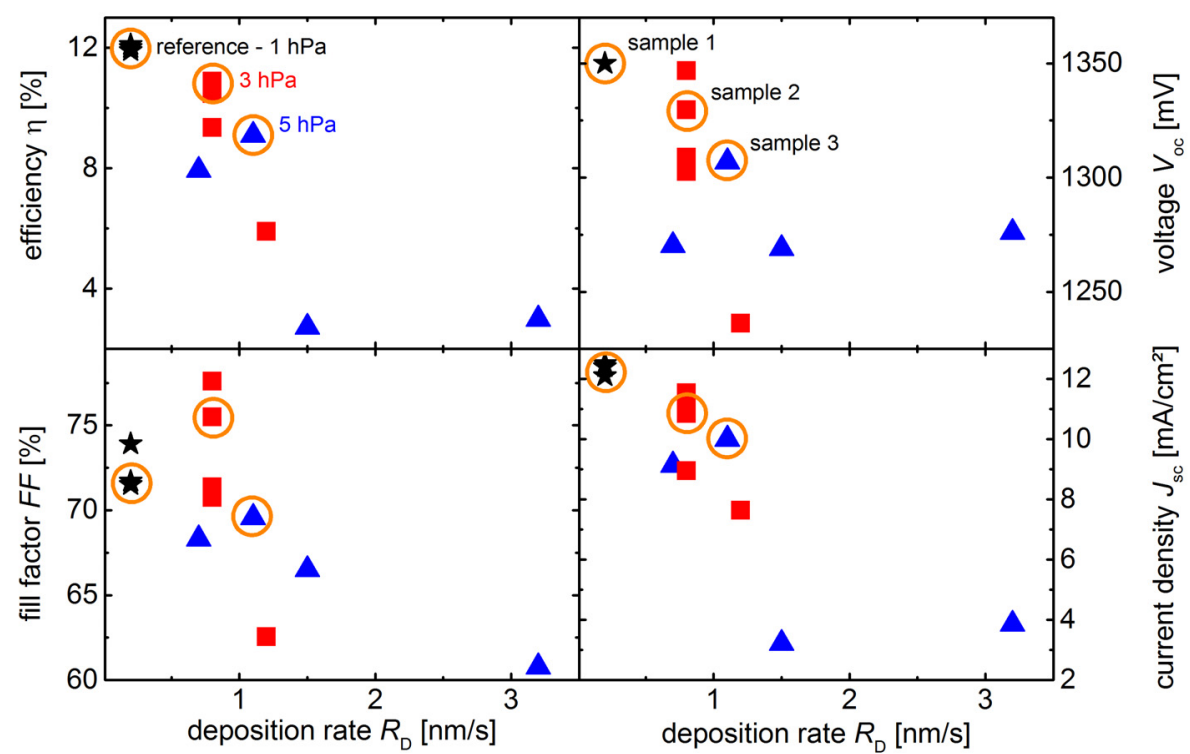

Fig. 1. Photovoltaic-parameters - efficiency $\eta$, fill factor $F F$, open-circuit voltage $V_{\text {oc }}$, and short-circuit current density $J_{\text {sc }}-$ as a function of the deposition rate $R_{\mathrm{D}}$. The circles indicate samples 1,2 , and 3 , which were further investigated by light induced degradation measurements.

of p-type $\mu \mathrm{c}-\mathrm{Si}: \mathrm{H}$, intrinsic $\mu \mathrm{c}-\mathrm{Si}: \mathrm{H}$, and n-type a-Si:H. A layer sequence of sputtered $\mathrm{ZnO}: \mathrm{Al} / \mathrm{Ag} / \mathrm{ZnO}: \mathrm{Al}$ served as the back contact of the final device. The active device area of $1 \mathrm{~cm}^{2}$ was defined by a laser scribing step. Apart from the deposition conditions of the $\mu \mathrm{c}-\mathrm{Si}: \mathrm{H}$ absorber layer of the bottom solar cell, all deposition parameters remained unchanged during the experiments. The deposition rate of the absorber layer of the bottom solar cell was varied by adjusting the deposition power, the silane concentration, and the deposition pressure. To ensure a similar total thickness of the terminated devices the deposition time of the bottom solar cells absorber layer was adjusted according to the deposition rate. The deposition power was varied between $20 \mathrm{~W}$ and $400 \mathrm{~W}$, the silane concentration was varied between $2.4 \%$ and $7 \%$, and the deposition pressure was varied between $1 \mathrm{hPa}$ and $5 \mathrm{hPa}$. The silane concentration SC is defined by the ratio of the silane $Q\left[\mathrm{SiH}_{4}\right]$ and the hydrogen $Q\left[\mathrm{H}_{2}\right]$ mass flow into the deposition chamber:

$$
S C=\frac{Q\left[\mathrm{SiH}_{4}\right]}{Q\left[\mathrm{SiH}_{4}\right]+Q\left[\mathrm{H}_{2}\right]}
$$

The absorber layers of the solar cells used as reference devices in this study were processed at a deposition power of $20 \mathrm{~W}$, an electrode distance of $11 \mathrm{~mm}$, a deposition pressure of $1 \mathrm{hPa}$, and an excitation frequency of $81.36 \mathrm{MHz}$.

The photovoltaic parameters of the solar cell - the conversion efficiency $\eta$, fill factor FF, open-circuit voltage $V_{\mathrm{oc}}$, and short-circuit current density $J_{\mathrm{sc}}$ - were measured using a double beam WACOM-WXS-140S-Super (Class A) sun simulator. External quantum efficiency measurements were performed at $25{ }^{\circ} \mathrm{C}$ without bias voltage under short-circuit conditions. The $J_{\mathrm{QE}}$ current density for each sub-cell of the tandem solar cells is calculated by the spectral integration of the EQE data and the AM 1.5 spectrum.

The photovoltaic-parameters and the external quantum efficiency (EQE) were measured on selected samples before and after $1000 \mathrm{~h}$ of light induced degradation (LID). During the light-soaking procedure the illumination was constant at $1000 \mathrm{~W} / \mathrm{m}^{2}$ and the temperature was held constant at $50{ }^{\circ} \mathrm{C}$. The following results present the data for the best solar cell out of the 18 solar cells fabricated for each sample set. The solar cell active area is $1 \mathrm{~cm}^{2}$.

\section{Results}

Figure 1 shows the photovoltaic-parameters as a function of the deposition rate of the absorber layer of the $\mu \mathrm{c}-\mathrm{Si}: \mathrm{H}$ bottom solar cell prepared at various deposition pressures. The best device performance with an efficiency of $12.1 \%$ was observed for the reference process at a deposition rate of $0.2 \mathrm{~nm} / \mathrm{s}$. With the exception of the reference solar cells all $\mu \mathrm{c}-\mathrm{S}: \mathrm{H}$ i-layers were processed at $3 \mathrm{hPa}$, and $5 \mathrm{hPa}$. The reference solar cell $\mu \mathrm{c}-\mathrm{S}: \mathrm{H}$ i-layer was processed at $1 \mathrm{hPa}$. For the solar cells where the $\mu \mathrm{c}-\mathrm{Si}: \mathrm{H}$ i-layer was processed at $3 \mathrm{hPa}$ the deposition power was varied between $50 \mathrm{~W}$ and $100 \mathrm{~W}$ with varying SC between $3.4 \%$ and $3.9 \%$. For the solar cells where the $\mu \mathrm{c}-\mathrm{Si}: \mathrm{H}$ i-layer was processed at $5 \mathrm{hPa}$ the deposition power was varied between $50 \mathrm{~W}$ and $400 \mathrm{~W}$ while the SC was varied from $2.4 \%$ to $7.0 \%$. The simultaneous variation of the deposition pressure, the deposition power, and the silane concentration was necessary to achieve device grade $\mu \mathrm{c}-$ $\mathrm{Si}: \mathrm{H}$ i-layers at elevated deposition rates [12] and thus to guarantee the optimal processing conditions for the fabrication of high quality thin-film solar cells. Processes leading to device grade microcrystalline silicon were presented 
Table 1. Deposition and photovoltaic-parameters for sample 1 (reference process) and samples 2 and 3 . Samples 2 and 3 are the samples which show the best efficiency for the sample set where the absorber layer of the bottom solar cell was processed at $3 \mathrm{hPa}$ and $5 \mathrm{hPa}$, respectively. The deposition parameters are abbreviated as follows: deposition pressure $p$, electrode distance $d$, deposition power $P$, silane concentration $S C$, and deposition rate $R_{\mathrm{D}}$. The photovoltaic parameters describe the efficiency $\eta$, the fill factor $F F$, the open-circuit voltage $V_{\mathrm{oc}}$, and the short-circuit current density $J_{\mathrm{sc}}$.

\begin{tabular}{cccccccccc}
\hline & $\begin{array}{c}p \\
{[\mathrm{hPa}]}\end{array}$ & $\begin{array}{c}d \\
{[\mathrm{~mm}]}\end{array}$ & $\begin{array}{c}P \\
{[\mathrm{~W}]}\end{array}$ & $\begin{array}{c}S C \\
{[\%]}\end{array}$ & $\begin{array}{c}R_{\mathrm{D}} \\
{[\mathrm{nm} / \mathrm{s}]}\end{array}$ & $\begin{array}{c}\eta \\
{[\%]}\end{array}$ & $\begin{array}{c}F F \\
{[\%]}\end{array}$ & $\begin{array}{c}J_{\text {sc }} \\
{\left[\mathrm{mA} / \mathrm{cm}^{2}\right]}\end{array}$ & $\begin{array}{c}V_{\text {oc }} \\
{[\mathrm{V}]}\end{array}$ \\
\hline Sample 1 & 1 & 11 & 20 & 5.2 & 0.2 & 12.1 & 73.9 & 12.1 & 1.35 \\
Sample 2 & 3 & 10 & 50 & 3.8 & 0.8 & 10.9 & 75.5 & 10.8 & 1.33 \\
Sample 3 & 5 & 10 & 100 & 3.8 & 1.1 & 9.1 & 69.6 & 10 & 1.31 \\
\hline
\end{tabular}

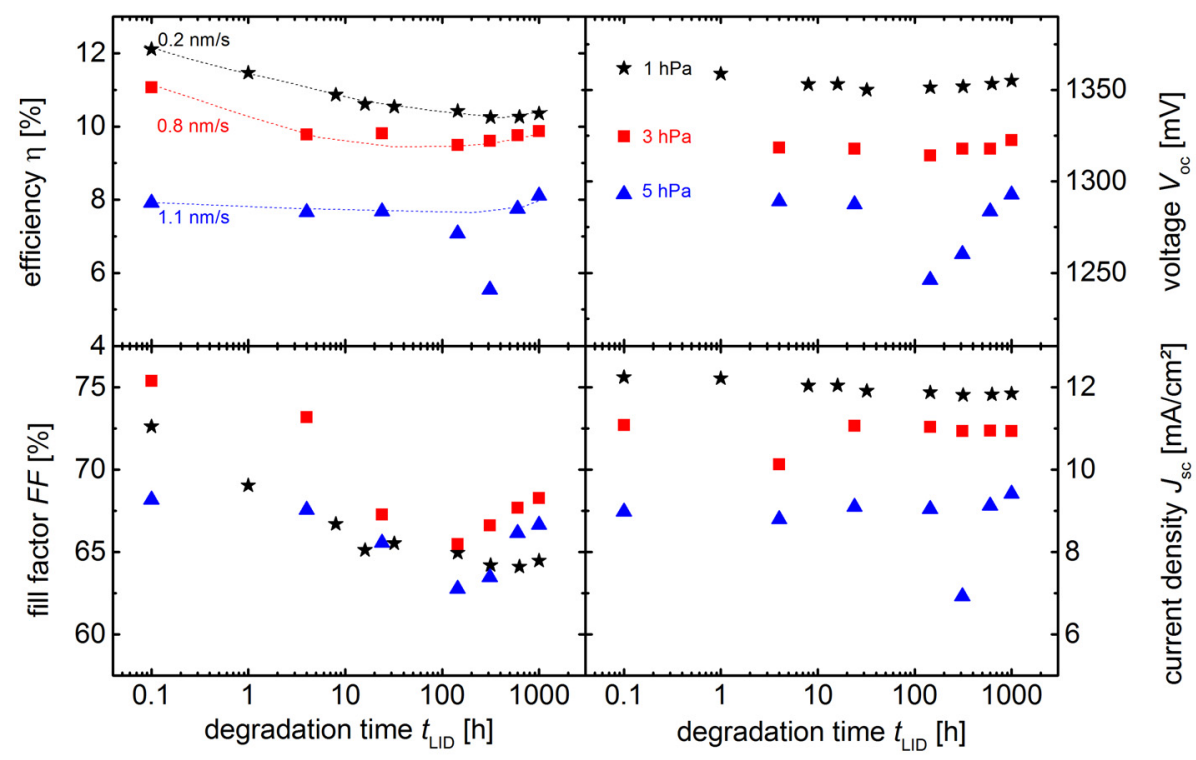

Fig. 2. Photovoltaic-parameters - efficiency $\eta$, fill factor $F F$, open-circuit voltage $V_{\mathrm{oc}}$, and short-circuit current density $J_{\mathrm{sc}}-$ as a function of time for light induced degradation (LID). The LID was performed with an illumination of $1000 \mathrm{~W} / \mathrm{m}^{2}$, and a controlled temperature of approximately $50{ }^{\circ} \mathrm{C}$.

in an earlier parameter study [12]. The criteria to classify silicon layers as device grade material have been taken from $[2,18]$. With increasing deposition rate, the efficiency of the solar cells decreases around 3\% (absolute scale) until a deposition rate of $1.1 \mathrm{~nm} / \mathrm{s}$. Increasing the deposition rate above $1.2 \mathrm{~nm} / \mathrm{s}$ resulted in a significant decrease of the device performance. The open-circuit voltage for those samples is below $1.3 \mathrm{~V}$ while the short-circuit current density is below $4 \mathrm{~mA} / \mathrm{cm}^{2}$. The best solar cells where the $\mu \mathrm{c}-\mathrm{Si}: \mathrm{H}$ i-layers were processed at elevated deposition pressures of $3 \mathrm{hPa}$ and $5 \mathrm{hPa}$ show efficiencies of $10.9 \%$ and $9.1 \%$ and deposition rates of $0.8 \mathrm{~nm} / \mathrm{s}$ and $1.1 \mathrm{~nm} / \mathrm{s}$, respectively. The photovoltaic-parameters and the depositions conditions of these solar cells together with the reference solar cell are summarized in Table 1 . In the following these solar cells will be referred to as sample 1, sample 2, and sample 3, according to Table 1. Comparing sample 1 and sample 3 an increase of the deposition rate from $0.2 \mathrm{~nm} / \mathrm{s}$ to $1.1 \mathrm{~nm} / \mathrm{s}$ resulted in a decrease of $45 \mathrm{mV}$ in the open-circuit voltage, and a decrease in the short-circuit current density of approximately $2 \mathrm{~mA} / \mathrm{cm}^{2}$. When compared to sample 1 , sample 2 also showed reduced open-circuit voltage and reduced short-circuit current density with increasing deposition rate, although the effect is not as strong as for sample 3. The open-circuit voltage decreases by $20 \mathrm{mV}$ while the short-circuit current density decreases by $1.3 \mathrm{~mA} / \mathrm{cm}^{2}$, with an increase of the deposition rate from $0.2 \mathrm{~nm} / \mathrm{s}$ to $0.8 \mathrm{~nm} / \mathrm{s}$. Samples 1 to 3 were further investigated by light-induced degradation (LID) and EQE measurements.

Figure 2 shows the photovoltaic-parameters of samples 1 to 3 as function of the degradation time. The efficiency of sample 1 decreases from $12.1 \%$ to $10.4 \%$ after $1000 \mathrm{~h}$ of LID. For sample 2 the efficiency of the solar cell decreases from $10.9 \%$ to $9.9 \%$ after the light soaking procedure. For sample 3 a reduction in the solar cells efficiency from $9.1 \%$ to $7.9 \%$ within the first LID cycle is observed. Afterwards the efficiency stabilizes around $8 \%$ and doesn't show any further degradation with proceeding LID. There is a strong decrease in $J_{\mathrm{sc}}$ and $V_{\mathrm{oc}}$ of sample 3 at degradation times of $150 \mathrm{~h}$ and $300 \mathrm{~h}$. This is attributed to contacting issues during the measurement of the IV characteristic. Within the uncertainty of the measurement setup, there is no dependency of the $J_{\mathrm{sc}}$ or $V_{\mathrm{oc}}$ on the degradation time, for any sample.

For the timeframe of $0-100 \mathrm{~h}$ of LID, the fill factors of all samples decreased with increasing degradation time. After $100 \mathrm{~h}$ of LID the fill factors for all three samples 


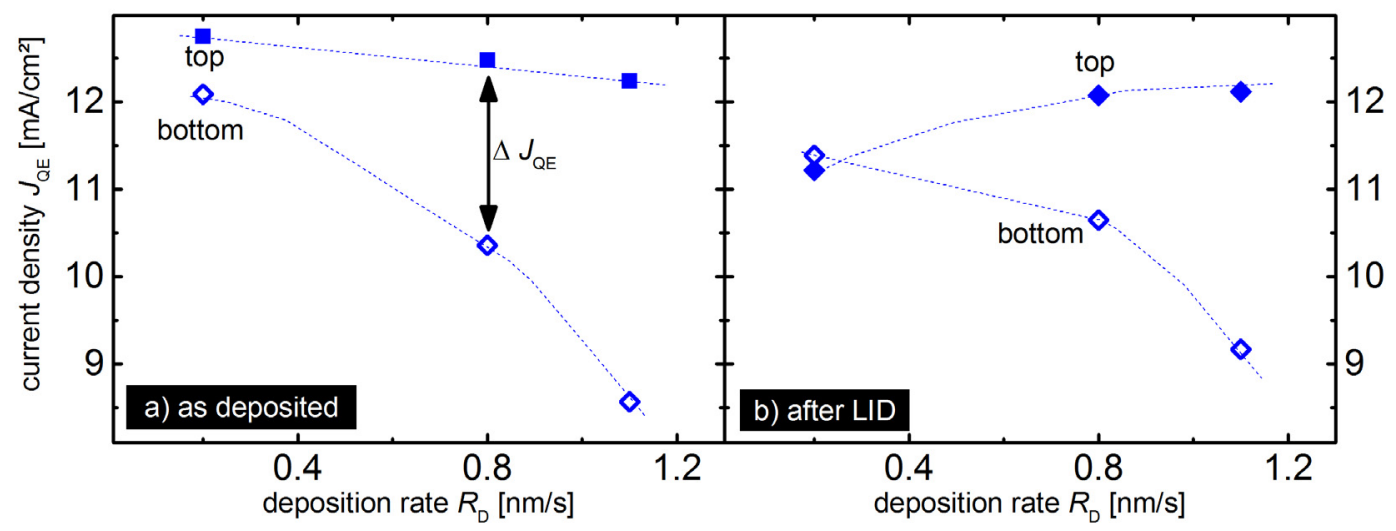

Fig. 3. Current density $J_{\mathrm{QE}}$ of the top and the bottom solar cells, derived from EQE measurements, as a function of deposition rate $R_{\mathrm{D}}$ before (a) and after (b) $1000 \mathrm{~h}$ of light induced degradation.

increases slightly with increasing degradation time. However, the interpretation of the fill factor should be taken with care. For example a high value of $F F$ can be caused by a mismatch between the currents generated by the top and the bottom solar cell. Thus, it is seen that the current matching between a-Si:H top solar cell and $\mu \mathrm{c}-\mathrm{Si}: \mathrm{H}$ bottom solar cell changes with proceeding degradation time.

Figure 3 shows the current density $J_{\mathrm{QE}}$ derived from EQE measurements for top and bottom solar cell as a function of deposition rate $R_{\mathrm{D}}$ before (Fig. 3a) and after (Fig. 3b) $1000 \mathrm{~h}$ of LID. Before LID the $J_{\mathrm{QE}}$ generated by the top and the bottom solar cell decreases with increasing deposition rate.

After LID the $J_{\mathrm{QE}}$ generated by the top solar cell increases slightly with increasing deposition rate, whereas the $J_{\mathrm{QE}}$ generated by the bottom solar cell decreases with increasing deposition rate. The values for the $J_{\mathrm{QE}}$ for the top solar cells are reduced after LID compared to the initial values. Prior to LID all samples are limited by the current of the bottom solar cell in the as-deposited state. After the LID samples 2 and 3 are still limited by the current of the bottom solar cell whereas sample 1 shows good current matching conditions between the a-Si:H top and $\mu \mathrm{c}-\mathrm{Si}: \mathrm{H}$ bottom solar cell. The quality of the matching between the top and the bottom solar cell current is visually expressed by the difference $\left(\Delta J_{\mathrm{QE}}\right)$ between the $J_{\mathrm{QE}}$ values for top and bottom solar cell for each sample. After LID, the difference $\Delta J_{\mathrm{QE}}$ decreases for sample 1 from $0.66 \mathrm{~mA} / \mathrm{cm}^{2}$ to $0.17 \mathrm{~mA} / \mathrm{cm}^{2}$, for sample 2 from $2.1 \mathrm{~mA} / \mathrm{cm}^{2}$ to $1.4 \mathrm{~mA} / \mathrm{cm}^{2}$, and for sample 3 from $3.7 \mathrm{~mA} / \mathrm{cm}^{2}$ to $3 \mathrm{~mA} / \mathrm{cm}^{2}$.

Figures $4 \mathrm{a}-4 \mathrm{c}$ show the results of EQE measurements for samples 1,2 , and 3, respectively. The current density values $J_{\mathrm{QE}}$ for the top and bottom solar cells before and after LID are displayed in each figure. The initial values are displayed in bold face, and the EQE curves for the initial case are displayed as solid lines. The EQE curves for the stabilized cases are displayed by dashed lines. The EQE curve of the top solar cell as well as the bottom solar cell of the reference sample are both reduced by the LID (see Fig. 4a). The EQE of the top solar cell is reduced in the wavelength region between $380 \mathrm{~nm}$ and $580 \mathrm{~nm}$,

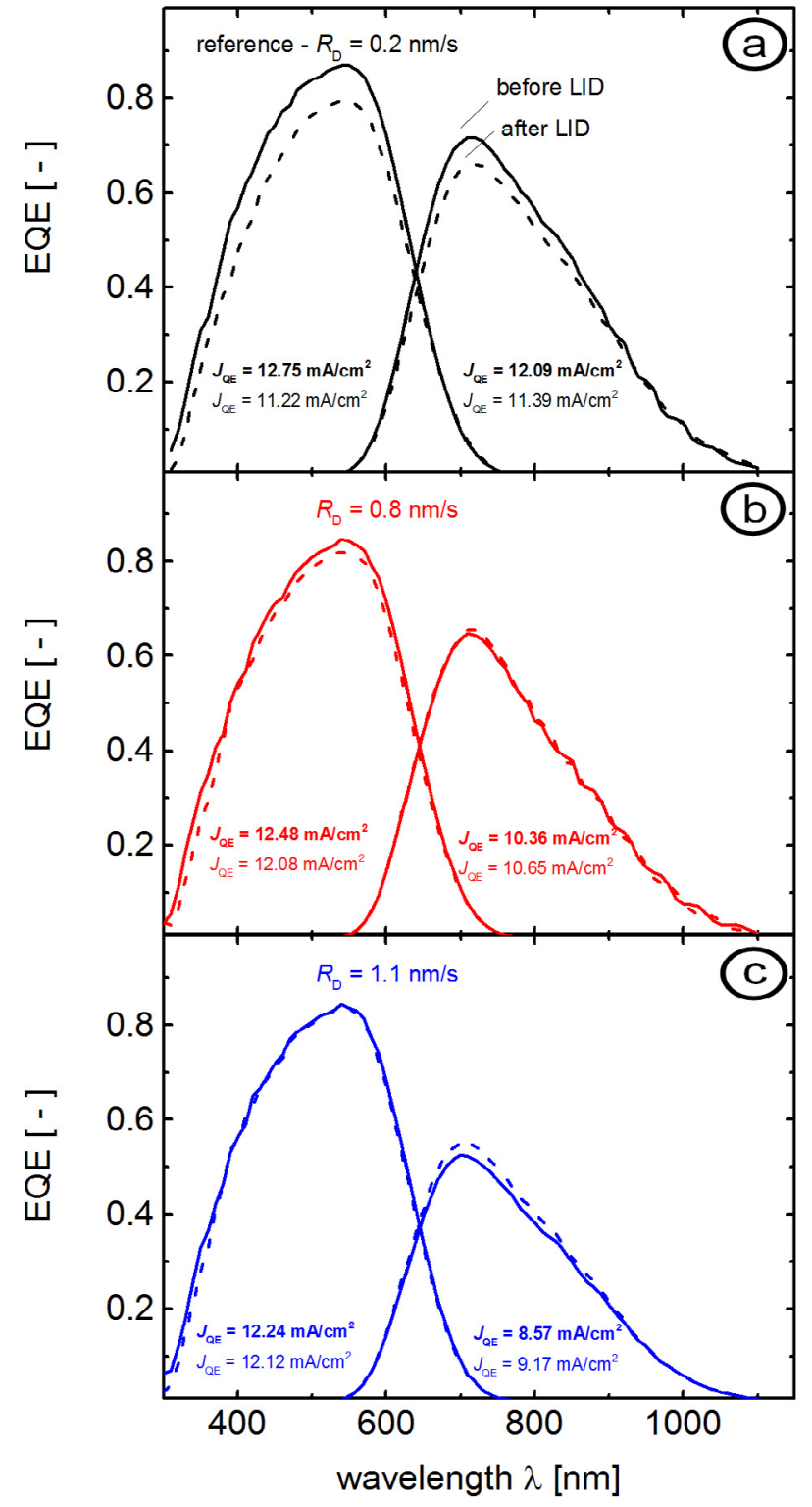

Fig. 4. EQE measurements for the top and bottom solar cells of sample 1 (a), sample 2 (b), and sample 3 (c). 
whereas the EQE of the bottom solar cell is affected in the wavelength region between $650 \mathrm{~nm}$ and $870 \mathrm{~nm}$. Both samples deposited at elevated deposition rates show a reduced EQE for the bottom solar cell compared to sample 1. Furthermore the reduction is more pronounced for the sample 3 compared to sample 2 . The top and bottom solar cells of sample 2 and 3 are less affected by the LID compared to the reference sample 1.

\section{Discussion}

The discussion part is organized in two parts. In the first part we discuss the effect of a varied deposition rate on the device performance. In the second part we present a model calculation about potential cost benefits when applying elevated deposition rates on an industrial scale.

To achieve high deposition rates for device grade microcrystalline silicon it is necessary to adjust the deposition parameters over a broad range. Adapting the deposition parameters may strongly influence the reactions in the glow discharge. Varying the deposition power or the deposition pressure for example leads to a modification of the ion bombardment of the growing film which in turn influences the growth properties of microcrystalline silicon [12]. The fact that the quantum efficiency of the top solar cell is not strongly affected by the application of the processes leading to high deposition rates for the absorbing layer of the bottom solar cell shows the energies of the bombarding ions are not sufficient to damage the i-n interface of the top solar cell. The decrease of the opencircuit voltage and the short-circuit current density can be attributed to a deterioration of the p-i interface of the bottom solar cell.

Samples 2 and 3 show less degradation of the bottom solar cells compared to sample 1 . This can be attributed to the effect that microcrystalline layers processed at elevated deposition rates grow with a pronounced Raman intensity ratio ${ }^{1}$. This assumption is supported by the reduced open-circuit voltage seen in the as-deposited state of the solar cells with increased deposition rate.

A slight increase of the efficiency of sample 2 and 3 is observed for degradation times beyond $100 \mathrm{~h}$ (see Fig. 2). Additionally, an increase of the fill factor is observed for all samples for degradation times exceeding $100 \mathrm{~h}$. Both effects might be attributed to a bottom limited current device and the improved current matching conditions caused by light induced degradation (see Fig. 3).

Together with industrial partners we are investigation within the "Fast Track" project (see acknowledgements) the possibility to scale processes which yield high deposition rates from laboratory scale to industry scale. To deduce a value for the cost benefits that can be used to compare both processes, a model calculation is presented. We assume that there are no further losses in the device performance during the up-scaling of the processes to large areas. Furthermore we do not include interconnection losses which may be introduced during the module fabrication

\footnotetext{
1 S. Michard, to be published (n.d.).
}

process. Considering the efficiency of sample 1 of $12.1 \%$ and an illumination intensity of $1000 \mathrm{~W} / \mathrm{m}^{2}$ together with the processing time of $180 \mathrm{~min}$ we can calculate the output for the chamber to be $40.33 \mathrm{~W} /\left(\mathrm{m}^{2} \mathrm{~h}\right)$.

$$
12.1 \% \stackrel{1000 \frac{\mathrm{W}}{\mathrm{m}^{2}}}{\longrightarrow} 121 \mathrm{~W} / \mathrm{m}^{2} \stackrel{/ 180 \mathrm{~min}}{\longrightarrow} 40.3 \mathrm{~W} /\left(\mathrm{m}^{2} \mathrm{~h}\right) .
$$

For sample 2, with an efficiency of $10.9 \%$ and a processing time of $70 \mathrm{~min}$ for the absorber layer of the bottom solar cell, we can calculate in an analogous way an output value of $93.4 \mathrm{~W} /\left(\mathrm{m}^{2} \mathrm{~h}\right)$. Thus by the introduction of processes leading to elevated deposition rates it is possible to increase the output of the i-chamber by a factor of 2.3 .

\section{Conclusion}

The effect of the deposition rate of $\mu \mathrm{c}-\mathrm{Si}: \mathrm{H}$ absorber layers was investigated in the range of $0.2 \mathrm{~nm} / \mathrm{s}$ and $3.2 \mathrm{~nm} / \mathrm{s}$ on the performance of thin-film silicon tandem solar cells. For a deposition rate of $0.8 \mathrm{~nm} / \mathrm{s}$, which corresponds four times the deposition rate of the reference process, an initial efficiency of $10.9 \%$ with a stabilized efficiency of $9.9 \%$ was observed. Despite the reduction in efficiency of $1.2 \%$ for the sample processed at a deposition rate of $0.8 \mathrm{~nm} / \mathrm{s}$ compared to the reference solar cell, calculations show that the output of the deposition system in terms of Watts per hour and area can be increased by a factor of 2.3 due to reduced processing times.

The authors thank A. Schmalen and J. Wolff for technical support and L. Nießen, C. Grates, C. Zahren for support with characterization setups. Assistance provided by A. Bauer, H. Siekmann, and U. Gerhards for the fabrication of $\mathrm{ZnO} / \mathrm{Ag}$ back contacts is greatly appreciated. The authors thank U. Rau for constant support, encouragement and for rewarding discussions. We acknowledge the "Bundesministerium für Umwelt, Naturschutz und Reaktorsicherheit" (Project "Quick $\mu \mathrm{c}-\mathrm{Si}$ ", Contract No. 03225260C). A part of this work was carried out in the framework of the FP 7 project "Fast Track", funded by the European Union under grant agreement No. 283501.

\section{References}

1. H. Keppner, J. Meier, P. Torres, D. Fischer, A. Shah, Appl. Phys. A: Mater. Sci. Proc. 69, 169 (1999)

2. O. Vetterl, F. Finger, R. Carius, P. Hapke, L. Houben, O. Kluth, A. Lambertz, A. Mück, B. Rech, H. Wagner, Sol. Energy Mater. Sol. Cells 62, 97 (2000)

3. K. Yamamoto, T. Suzuki, M. Yoshimi, A. Nakajima, Jpn J. Appl. Phys. 36, 569 (1997)

4. G. Nakamura, K. Sato, Y. Yukimoto, in 16th IEEE Photovolt. Specialist Conf., New York, 1982, pp. 13311337

5. J. Yang, A. Banerjee, S. Guha, Appl. Phys. Lett. 70, 2975 (1997)

6. S. Hänni, G. Bugnon, G. Parascandolo, M. Boccard, J. Escarré, M. Despeisse, F. Meillaud, C. Ballif, Prog. Photovolt.: Res. Appl. 21, 821 (2013) 
7. S. Kim, J. Chung, H. Lee, J. Park, Y. Heo, H. Lee, Sol. Energy Mater. Sol. Cells 119, 26 (2013)

8. S. Guha, J. Yang, B. Yan, Sol. Energy Mater. Sol. Cells 119, 1 (2013)

9. A. Shah, E. Moulin, C. Ballif, Sol. Energy Mater. Sol. Cells 119, 311 (2013)

10. Y. Mai, S. Klein, R. Carius, J. Wolff, A. Lambertz, F. Finger, X. Geng, J. Appl. Phys. 97, 114913 (2005)

11. A. Gordijn, A. Pollet-Villard, F. Finger, Appl. Phys. Lett. 98, 211501 (2011)

12. S. Michard, M. Meier, B. Grootoonk, O. Astakhov, A. Gordijn, F. Finger, Mater. Sci. Eng. B 178, 691 (2012)

13. L. Guo, M. Kondo, M. Fukawa, K. Saitoh, A. Matsuda, Jpn J. Appl. Phys. 37, 1116 (1998)
14. A. Matsuda, J. Non-Cryst. Solids 338-340, 1 (2004)

15. F. Finger, P. Hapke, M. Luysberg, R. Carius, H. Wagner, M. Scheib, Appl. Phys. Lett. 65, 2588 (1994)

16. J. Meier, E. Vallat-Sauvain, S. Dubail, U. Kroll, J. Dubail, S. Golay, L. Feitknecht, P. Torres, S. Fay, D. Fischer, A. Shah, Sol. Energy Mater. Sol. Cells 66, 73 (2001)

17. U. Graf, J. Meier, U. Kroll, J. Bailat, C. Droz, E. VallatSauvain, A. Shah, Sol. Energy Mater. Sol. Cells 427, 37 (2003)

18. O. Vetterl, A. Gross, T. Jana, S. Ray, A. Lambertz, R. Carius, F. Finger, J. Non-Cryst. Solids 299-302, 772 (2002)

Cite this article as: S. Michard, V. Balmes, M. Meier, A. Lambertz, T. Merdzhanova, F. Finger, Microcrystalline silicon absorber layers prepared at high deposition rates for thin-film tandem solar cells, EPJ Photovoltaics 4, 45201 (2013). 